\title{
The Global Agenda Council on the Ageing Society: Policy Principles
}

\author{
S. Jay Olshansky, University of Illinois at Chicago \\ Simon Biggs, University of Melbourne \\ W. Andrew Achenbaum, University of Houston \\ Gerald C. Davison, University of Southern California \\ Linda Fried, Columbia University \\ Gloria Gutman, Simon Fraser University \\ Alexandre Kalache, New York Academy of Medicine \\ Kay-Tee Khaw, University of Cambridge \\ Alvaro Fernandez, SharpBrains \\ Suresh I. S. Rattan, Aarhus University \\ Renato Maia Guimarães, Universidade de Brasília \\ Colin Milner, International Council on Active Aging \\ Robert N. Butler, International Longevity Center
}

\section{Abstract}

In 2008, the World Economic Forum (WEF) created the Global Agenda Councils - an amalgamation of scientists, public policy makers, academics, physicians and business leaders with the task of devising transformational innovation in global governance for the purpose of advancing knowledge and collaboratively developing solutions for the most crucial issues facing humanity. Because of its overarching effect on many aspects of society, a Council was created to address global issues associated with an ageing society. The Councils have the task of challenging prevailing assumptions, monitoring trends, proposing solutions, devising strategies, making public policy proposals and evaluating the effectiveness of actions using measurable benchmarks. This report is the first product of the WEF's Council on the Ageing Society - our goal is to lay down the initial principles that will guide our actions in the coming years.

According to conventional wisdom, growing numbers of people living to advanced ages pose challenges for developing and mature societies alike (Longman, 1987; Peterson, 2000). Doomsayers assert that elders will increasingly claim a disproportionate share of financial and health care resources, straining government funds and business and household budgets (Kotlikoff and Burns, 2005). The problem is thought to become more burdensome as life expectancy increases and populations age, thus diverting attention from other global priorities such as climate change (Friedland and Summer, 1999; Speth, 2005). Developing nations will also experience population ageing just like the rest of the world.
However their experience is opposite to that of developed countries which became rich before they grew old; developing countries are growing old before they become rich (Kalache et al., 2005). This will produce complicated and challenging demographic and economic conditions. These considerations have important policy implications, in particular for how societies view current and future cohorts of older adults and how resources can and should be allocated to maximise human capital in ageing populations.

According to the Council on the Ageing Society, this negative scenario does not have to be our fate. There are also significant benefits and opportunities in an 
ageing and longer-lived society that require international approaches to be realised. At present, however, there is a disconnect between conventional negative assessments of growing older and the present and projected roles of older people as producers and contributors to the social and economic wealth of nations.

Policy makers in all countries have much to learn about the impact of the longevity revolution on institutional sustainability within their borders and abroad because so few have experienced dramatic upward shifts in their age structure. They would do well to follow the example of Japanese politicians, business executives and civic leaders who recognised three decades ago that dramatic gains in life expectancy were altering fundamental components of their economy and polity. Japan 2000 remains a landmark blueprint, which successive governments heeded even as the Japanese economy took unexpected and undesirable turns. Few leaders have yet to come to terms with global ageing, although it is evident that nations throughout the developed and developing world are beginning to plan for this demographic shift (Harper, 2006; Lutz et al., 2008). Educating the political leaders and the citizenry of all nations about population ageing is a critical priority, for policy initiatives are effective ways to address structural lags in developing and developed societies alike.

For instance, most nations need to rethink their employment, educational and income-maintenance policies in light of increasing demands for and by older workers for meaningful jobs. Seasoned workers around the world currently seek out ways to use their experience in part-time positions, as volunteers, as grandparents who contribute to family life, and in second, third or fourth careers (Freedman, 1999; Laslett, 1991; Lutz et al., 2007; Philibert, 1968), and there is reason to believe this will continue as some of today's cohorts of older adults are physically and cognitively healthier than any preceding ones (Achenbaum, 2005; Cassel, 2005; Langa et al., 2008; Martin et al., 2009). An overall salubrious forecast is warranted thanks to public health interventions, advances in medicine and technology, better access to geriatric-expert health professionals and social service support groups, and models of innovative, new types of social institutions.

The Council on The Ageing Society has four aims:

1. We emphasise the power of knowledge as a policy tool. Evidence-based information about individual and societal ageing must replace myths of senescence and ageist assumptions among power brokers and idea makers for whom the challenges of gerontology have largely been a peripheral issue.

2. We contend that early and repeated preventive care 'interventions' (especially in health behaviours and geriatric medicine) and 'preventive' measures (such as social integration, design of cities and lifelong learning so that workers can upgrade skills) will delay the onset of late-life difficulties.

3. We recommend that public and private agencies as well as organisations in the independent sector capitalise on the demonstrable wisdom and untapped potential of older adults as mentors and repositories of insights, and create heretofore unrealised but meaningful roles for older adults, meeting important societal needs and serving as creators of new types of societal approach.

4. We recommend the development of new metrics for an ageing world that capture benefits as well as costs for mature and for developing economies.

\section{The challenges of ageing-related transitions}

Several major ageing-related transitions in human society have profoundly influenced our modern world, and will continue to influence every aspect of our lives in the future. They include: the rapid increase in life expectancy in developed nations in the 20th century; associated reductions in infectious diseases and declining early age and maternal mortality; medical advances in recent decades that led to declining middle- and old-age mortality; rapid demographic shifts in the age structure known as population ageing (Kinsella and $\mathrm{He}, 2008$ ); and a notably different pattern of change in developing nations. The effects of these transitions impact national economies, personal finance, pension schemes of companies and governments, social institutions, health care, housing, science, technology and basic values involving quality of life. However, population ageing and the extension of life are products of success, not failure. As such, it is inappropriate to portray either of these trends as undesirable, or as an economic crisis waiting to happen, as if it is an unwelcome demographic destiny that awaits us all (Gee and Gutman, 2000). Given the reality that the world is ageing, it is essential that we redesign society to realise the benefits and address the challenges.

As a global phenomenon, the full effect of population ageing has yet to be experienced. In developed countries the leading edge of the large cohort known as the Baby Boom Generation, born during the middle of the 20th century, will begin to reach age 65 within the next few years, the traditional age of retirement in many countries. From that year forward, governments and businesses will have unprecedented numbers of older persons. However, population ageing is not just a developed world phenomenon. Some of the most difficult and urgent challenges will occur in developing nations where the largest number of older people will live, and there is reason to believe that these nations are ill 
equipped to handle the forthcoming rapid transition given other health, economic and environmental issues they face (Kalache et al., 2005; Kinsella and He, 2008). It must also be recognised that current and future cohorts of older persons are heterogeneous, and this diversity is expected to grow as the size of elderly cohorts swells (Kinsella and He, 2008). Some will be frail and will make considerable demands on existing institutions; many will be healthy (and some wealthy), and they will continue to serve as resources for their families, communities and countries (United Nations, 2003).

\section{The linkage between the economic crisis and issues faced by the Council on the Ageing Society}

There are challenges associated with the growing numbers of older persons during a period of economic uncertainty. Automobile manufacturers in the United States, for example, have now secured loans from the federal government first and foremost to pay off pension and health care obligations to their unions. In many parts of the world, newly emerging welfare systems will be placed under threat, increasing the likelihood of long-term cumulative disadvantage and associated preventable costs (Dannefer, 2003). Other challenges await age-entitlement programmes that provide social security and health care in nations throughout the world as people live longer than was expected when the programmes intended to finance their retirement were first devised (Olshansky, Carnes and Mandell, 2009). However, economists already recognise that declining fertility rates, while creating unprecedented job opportunities for young people in the short run, are going to result in a serious shortage of human capital in the long run (Estes et al., 2003; OECD, 2007).

The difficulties we face now include learning how to confront the challenges of population ageing without the prejudice that is often linked to a rising elderly population, and finding new and innovative ways to explore the opportunities that will allow us to celebrate and enhance the great success of our extended lives, and meet our social capital needs (Rowe et al., 2009, 2010). The current period of financial uncertainty therefore reinforces the need to examine the positive role that older people can play in both developing and more advanced economies, both as producers (direct and indirect) and as generative and stabilising influences in their communities. It also brings into focus the relationship between social change, personal planning and the need for a range of products, services and changes in infrastructure that can provide continuity and stability across the adult life course. A failure of social institutions to address population ageing and the needs of older adults presents a threat to social cohesion, not simply among older people themselves, but for citizens of all ages and their governments.

\section{Positive attitudes to ageing, associated roles and intergenerational relationships}

Our world does not offer meaningful and productive roles for older adults. At the same time, there are substantial unmet societal needs that older adults could help address. New models of such roles have recently begun to emerge - some intentionally designed to simultaneously improve health for the older adult participants (Carlson et al., 2008; Frick et al., 2004; Fried et al., 2004; Glass et al., 2004). We know that as people age, body, mind, purpose and context increasingly affect each other, so that enhancement in one area improves wellbeing in the others (Baltes et al., 2005). However, there is no guarantee that the priorities at one age, midlife, for example, will be the same as those of later life - we should not simply transpose one set of values on to another. Often, age-related changes are qualitative rather than quantitative in nature (Biggs, 2005). Generative contributions sought in late life can bring substantial benefits to our societies, but will require modified or different forms of productivity and social inclusivity. The elimination of cumulative disadvantage across the lifespan, for example, will be required to remove preventable barriers to social engagement in later life. We need, as a society, to develop the skills and institutions to adapt to and integrate age-related innovation.

\section{Ageism}

While explicit examples of intergenerational conflict are limited, there is widespread evidence (across geographic and cultural boundaries) of ageism - that is, resistance to include an ageing perspective into decision making and design, and a tendency to prioritise the perspectives of younger stages of the life course (Butler, 1969). Ageism or age discrimination is known to exist in the workplace as well as in industries such as health care, media and entertainment, in spite of the enactment of antidiscrimination laws in some countries (Butler, 2002; Kane and Kane, 2005).

\section{Health begets wealth}

It has been long understood that as societies become wealthier they are in a better position to provide benefits for their citizens (Nordhaus, 1998). The suggestion that the reverse is true - that health and longevity create wealth - has also been supported by empirical evidence (Bloom et al., 2004; Bloom and Canning, 2000; Nordhaus, 2003). One mechanism for the interrelationship between health and wealth is found across 
generations where it has been shown that a healthy childhood through adult life contributes to a more productive old age (Cutler et al., 1998).

\section{Intergenerational conflict}

While issues such as ageism and mistreatment exist, there is little evidence that intergenerational conflict currently takes place in an organised form (Antonucci et al., 2007). Intergenerational conflict is not an inevitable consequence of population ageing, the extension of life or a shifting age structure.

\section{A proper view of ageing}

Ageing is almost always associated with notions of loss, decline and decay. The fact is that in spite of decrements that accrue among all people who live to older ages, many people are still able to live healthy, active and productive lives into extreme old age (Christensen et al., 2008; Perls et al., 1999). Further, scientists are just beginning to recognise the potential for important creativity that is distinctly associated with chronological age and may offer untapped opportunities for societal innovation and problem-solving roles, among others (Cohen, 2001).

\section{Is ageing an issue only for the 'developed' world?}

There is now definitive evidence that population ageing will affect all societies, and that it will be more rapid and more extensive in developing economies than had previously been experienced elsewhere (Kinsella and $\mathrm{He}$, 2008; United Nations, 2007; WHO, 1984, 2001). Older people of the future are more likely to be urban, female and living in less developed regions of the world (Kalache et al., 2005; World Health Organization (WHO), 1984, 2001).

\section{Re-designing cities, communities and social institutions}

Preventive health depends upon an environment that supports healthy living and a sense of well-being and of community. The design of buildings, communal spaces, open spaces, transport and communication systems are a key element in facilitating active ageing and enhancing the 'age-friendliness' of both rural and urban environments (Keating, 2008; WHO, 2007). At the infrastructural level, age-friendly environments need to be developed to promote social integration for all levels of functioning older adults. This will require newly designed public and private spaces, systems for transport, communication and the delivery of services that facilitate participation by people with disabilities.

\section{Gerontechnology}

Gerontechnology is an interdisciplinary field concerned with the design and development of the physical environment and technologies, for use by older adults, caregivers, health service providers and ageing service providers, to enhance the lives of seniors in domains of human activity such as housing, communication, transportation, work, health and leisure (Van Bronswijk et al., 2009). The availability of ingenious new technologies can support longer and higher-quality lives; and an increased general awareness of the importance of the physical environment can influence how well people live.

\section{Lifelong learning, ageing and economic destiny}

\section{Ageing and our economic destiny}

Economic policies are often predicated on the assumption that we are headed toward a global ageing disaster (Peterson, 2000). This line of reasoning does not take into account the health and economic benefits of healthy ageing. Attention needs to be paid to the development of new economic and demographic metrics that represent both sides of the ageing/economics equation.

\section{Pursuing healthy ageing}

We recommend the development and implementation of a range of population-based, community and public health approaches to health promotion and disease prevention, with a focus on chronic health problems and the appropriate goal of compressing disability into a shorter duration of time at the end of life. These interventions need to be cost-effective, intersectorial, emphasise a life course approach, be feasible to apply globally and based on current scientific evidence as outlined by the World Health Organization's 'Active Ageing Policy Framework' which has influenced policy development in both developed and developing countries since it was issued in 2002. The WHO defines active ageing as the process of optimizing opportunities for health, participation and security in order to enhance quality of life as people age'. Such opportunities exist at all stages of life; the earlier they are seized, the larger the benefits although there is never a 'too late' threshold. The WHO framework outlines the various determinants of active ageing: gender and culture, which are transversal, influencing all others, as well as access to services; behavioural determinants; personal; those related to the physical as well as to the social environment; and economic, each individually influencing the attainment of 'active ageing' while, at the same time, being interconnected (WHO, 2002). Health care systems should be 
designed to include a coordinated continuum of care focused on prevention or maintenance of chronic disease, disability, frailty and other geriatric conditions (Fried and Hall, 2008).

\section{Lifelong learning}

Traditionally, educational programmes have been targeted at younger populations with little consideration given to older groups. However, ageing of the workforce in combination with anticipated changes in the nature of work and patterns of employment will require lifelong and continuous education and training as well as opportunities for job retraining (Walker, 1997). These education opportunities will enable people to work longer in satisfying jobs and must be made more flexible and accessible to older groups. Programmes that promote intergenerational learning should be expanded to facilitate shared learning between age groups, including knowledge of life course development.

\section{Changing work roles}

The traditional work role model has been of increasing responsibility and seniority with upward trajectory over time for individuals until retirement. The raising or abolishing of the age threshold for retirement means this model is no longer viable. Society will need to learn how to develop and accept new types of work trajectory modelled on different roles at different stages of life, with older people moving into new work roles (such as mentorship) that can capitalise on their experience (Walker, 1997).

\section{Civic engagement and roles}

Older adults have served many roles in society: as repositories of community knowledge and the communicators of this knowledge to subsequent generations; as grandparents and - increasingly - great-grandparents; informal caregivers; community watchdogs; and in some communities and societies, providers of community service. Beyond these roles, there are few civic or secular institutions to provide new kinds of meaningful roles for older adults in an ageing society. Older adults are increasingly seeking generative opportunities, roles in which they can make significant contributions to society and remain productive (Morrow-Howell et al., 2001). However, most societies are unprepared to utilise this new source of social capital, and particularly to offer roles that meet the needs of older adults to make significant societal contributions (Fried et al., 2004; Rebok et al., 2004). To accomplish this will require significant investment, both public and private, in design of effective roles and creation of new social institutions.

\section{Preventive health approaches and extension of healthy life}

\section{Extension of healthy life}

Contrary to the myth that healthy life cannot be further extended, scientists have known for decades that interventions already exist to delay the onset and age progression of major fatal and disabling diseases. Recent evidence indicates that the extension of healthy life expectancy, even at older ages, has already been achieved in some parts of the world, and these positive changes remain plausible targets for current and future health interventions (Jagger et al., 2007). The same methods may be used to improve or maintain mental and physical functioning.

\section{Modulating ageing in people}

In recent decades, scientists have learned enough about the biological ageing processes that many believe it will become possible to slow ageing in humans (Miller, 2009; Rattan, 2005, 2008; Sierra et al., 2008). We contend that the social, economic and health benefits that would result from such advances may be thought of as 'longevity dividends' (Olshansky et al., 2006, 2009), and that they should be robustly pursued by all nations as the new and most efficient approach to health promotion and disease prevention in the 21st century (Butler et al., 2008).

\section{There is no anti-ageing 'medicine'}

Advocates of what has become known as anti-ageing 'medicine' claim that it is now possible to slow, stop or reverse ageing through existing medical and scientific interventions (Breen, 2004; Klatz, 1997). The controversial nature of these claims arises from a combination of the inability of scientists to definitively measure biological ageing, and the lack of empirical evidence to support these claims (Olshansky et al., 2002a, 2002c; Wick, 2002). Therefore, claims made by practitioners of what is known as anti-ageing 'medicine' that they have interventions available today that will slow, stop or reverse ageing in people have not been tested for safety and efficacy using scientific methods and currently have no basis in fact (GAO, 2001; Holliday, 2009; Olshansky et al., 2002b; US Senate, 2001). However, there is a growing body of empirical research suggesting that such interventions are forthcoming (Butler et al., 2008; Miller, 2009; Rae et al., 2010; Rattan, 2008; Sierra et al., 2008).

\section{Psychological/psychiatric disorders among older adults}

Psychological problems like anxiety and depression compromise physical health and quality of life for people 
across the lifespan. Older adults are not immune from these challenges, or from suicide (Blazer and Hybels, 2009; Zarit and Zarit, 1998). Psychological problems can interfere with the effective treatment of medical problems such as compliance with therapeutic regimens and help-seeking activities (Lenze et al., 2001), and it is recognised that psychological problems are often misdiagnosed among older adults (Knight, 2004). The demonstrated efficacy of psychological interventions for problems such as anxiety and depression is as great as that of psychoactive drugs, especially in the long term, and should be pursued in both research and application to a greater extent than is currently the case (Hollon et al., 2006; Hollon and Dimidjian, 2009; Knight et al., 2006).

\section{Technology to assess and help maintain cognitive fitness}

Assessing and helping maintain cognitive functions is emerging as an important health care priority where gerontechnology can complement lifestyle factors like physical exercise, lifelong learning and civic engagement. More research is needed to identify and compare longterm effects of a variety of interventions in impaired and healthy populations (Papp et al., 2009), and innovative public-private partnerships will be required to ensure the marketplace matures in a rational and sustainable manner, both through health care and non-health care channels, bridging gerontology, geriatrics, cognitive neuroscience and neuropsychology.

\section{Social inequality in health and duration of life}

Life expectancy differentials between and within populations are a sign of inequalities in society. There is much that can be done today to reduce or eliminate these inequalities. Whatever form this takes will have to involve a social agenda that focuses on the need for society to look after the welfare of its disadvantaged and disenfranchised and not just those who are privileged in their access to quality education and health care.

\section{Resource problems in gerontology}

There is a serious shortage of human resources in gerontology, spanning research and application. This shortage is true for mature and for developing economies. More physicians and other health professionals need to be trained in geriatrics (Mitka, 2002), and there is a need for more social scientists (Birren and Schaie, 2006, p. xv), policy experts (Baltes and Smith, 2003), biologists (National Research Council, 2005, p. 5) and practitioners (Kovner et al., 2002; Scharlach et al., 2000) to be trained in gerontology.

\section{Conclusions}

A global concern towards population ageing is relatively recent and only gained impetus at the Second World Assembly on Ageing organised by the United Nations in Madrid in 2002. This Assembly launched the Madrid International Plan of Action on Ageing (MIPAA) which has several recommendations under its three prioritised strategic areas: ageing as a development issue; health and well-being; and the social and physical environment. If fully implemented by all the 192 countries that have endorsed it, societies would go a long way towards the aspirations outlined by us in this article. However, MIPAA is not enforceable and therefore it lacks the strength that only 'hard' international law provides. Thus, we believe that the establishment of an enforceable international policy framework is imperative. In this regard efforts are on course that will hopefully culminate in the establishment at a UN level of an international convention to protect the rights of older people. Indeed, while older people are the fastest increasing age group worldwide, they are also the only vulnerable population subgroup still lacking such a convention - now adopted for the protection of the rights of children, women, indigenous populations, disabled persons, immigrants and so on. It is a glaring omission.

At the scientific and academic level global population ageing has led recently to a number of science-based initiatives designed to address the challenges and opportunities that ageing presents - these include the MacArthur Foundation's Research Network on an Ageing Society, the National Academy of Sciences and our effort through the World Economic Forum's (WEF) Global Agenda Council on the Ageing Society. Although the underlying theme of all of these major initiatives is the same (ageing is simultaneously a challenge and an opportunity for all of humanity), what makes the WEF effort unique is our explicit effort to seek out international cooperation on all fronts (medical, academic, scientific, business, etc.) to change and improve the face of ageing in the 21 st century.

A global policy toward ageing societies will need to be both specific to particular cultures and nation states and engage in shared development and coordination of common problems and solutions. It will therefore have elements of both subsidiarity, or policy learning, and joined-up policy innovation. While knowledge of the factors influencing ageing societies is developing swiftly on a number of fronts, there is a clear need to develop links and examine interactions across policy domains. What are the implications, for example, of the development of life-extending technologies for pension policy? What is the relationship between public policy that encourages productive workforce ageing and changing demands on health systems where these exist? How can 
the policy issues of ageing in the mature economies (e.g. social isolation and the retrenchment of services) and those of developing economies (e.g. historic absence of services for old age, migration, interdependency between generations) learn from each other and find solutions that fit local circumstances? In order to address the multiple policy concerns that ageing societies bring into focus, transnational joint efforts are required in order to take a truly global perspective forward. However, implementation will often depend upon local interpretation.

It is certainly true that the challenges associated with ageing faced by all of humanity are not felt equally throughout the world. There is no greater evidence for this than the fact that developing nations will experience this demographic phenomenon over an extremely short time frame relative to the experience of developed nations in the 20th century. Because developing nations will grow old before they mature economically, this will pose unique challenges to policy makers who have simultaneously to address health and economic concerns at the younger end of the age structure. Members of the Council on the Ageing Society at the WEF are uniquely positioned to help policy makers navigate through these unusual circumstances because of our background and experience in addressing these issues at a global level. Nevertheless, there are common threads to the challenges and opportunities associated with ageing that exist in all societies - including the myths about what it means to grow old - and it is these common elements that will be the focus of the Council's work in the near term.

In the final analysis, ageing is a global phenomenon with complexities unique to different parts of the world. Confronting the critical challenges and opportunities that accompany life extension and population ageing at the global level now will encourage a healthier, wealthier and more equitable ageing society in the 21st century. In this first publication of The Global Agenda Council on the Ageing Society at the WEF we set forth the basic principles that will guide our views, actions and policies in the coming years. Most important among them is the way in which we believe individuals and societies should be thinking about ageing relative to the myths, misconceptions and lost opportunities that are common themes throughout the developed and developing world. In a very important way, this is perhaps the most significant public policy recommendation that our Council will set forth. Nevertheless, responsibility for generating public policy and accountability once the recommendation is implemented will rest with government agencies in each country. Yet, we can learn from each other now as some nations are already going through the transition to an older society that other nations will not experience for decades. In subsequent publications, the Council will set forth detailed and concrete policy recommendations along with expected outcomes and tools to gauge success. Although there will be a focus on national and regional issues and country-specific recommendations, our primary focus will be on the development of public policy at the global level.

\section{Note}

The authors wish to thank another member of the 2008 WEF Council on The Ageing Society who commented on earlier drafts of the manuscript: Dr Aubrey de Grey. The former chair of the 2008 WEF Council on the Ageing Society was Dr Hiroshi Komiyama.

\section{Dedication}

This manuscript, the work of the Council on the Ageing Society of the World Economic Forum, and the actions of the Council that follow, are dedicated to the memory of our Council chair and leading figure in gerontology - Dr Robert Butler - who died on 4 July 2010 .

\section{References}

Achenbaum, W. A. (2005) Older Americans, Vital Communities. Baltimore, MD: Johns Hopkins University Press.

Antonucci, T. C., Jackson, J. S. and Biggs, S. (2007) 'Intergenerational Relations: Theory, Research, and Policy', Journal of Social Issues (special edition), 63 (4), pp. 679-902.

Baltes, P. B., Fruend, A. M. and Li, S. C. (2005) 'The Psychological Science of Human Ageing', in M. Johnson, V. L. Bengston, P. G. Coleman and T. B. L. Kirkwood (eds), The Cambridge Handbook of Age and Ageing. Cambridge: Cambridge University Press, pp. 275-291.

Baltes, P. and Smith, J. (2003) 'New Frontiers in the Future of Aging: From Successful Aging of the Young Old to the Dilemmas of the Fourth Age', Gerontology, 49, pp. 123-135.

Biggs, S. (2005) 'Beyond Appearances: Perspectives on Identity in Later Life and some Implications for Method', Journal of Gerontology: Social Sciences, 69B, pp. S118-S127.

Birren, J. W. and Schaie, K. W. (eds) (2006) Handbook of the Psychology of Aging, sixth edition. London: Elsevier Academic Press.

Blazer, D. G. and Hybels, C. F. (2009) 'Depression in Later Life: Epidemiology, Assessment, Impact, and Treatment', in I. H. Gotlib and C. L. Hammen (eds), Handbook of Depression, second edition. New York: Guilford, pp. 492-509.

Bloom, D. E. and Canning, D. (2000) 'The Health and Wealth of Nations', Science, 287 (5456), pp. 1207-1209.

Bloom, D. E., Canning, D. M. and Michael, J. (2004) 'The Effect of Improvements in Health and Longevity on Optimal Retirement and Saving'. NBER Working Paper Series: w10919.

Breen, M. (2004) 'Marketing Your Anti-aging Practice, or How to Make People Young ... and Make Money Too', Paper presented at the Twelfth International Conference on Anti-Aging, 20-22 August, Chicago, IL, American Academy of Anti-Aging Medicine.

Butler, R. N. (1969) 'Age-ism: Another Form of Bigotry', The Gerontologist, 9 (41), pp. 243-246.

Butler, R. N. (2002) Why Survive? Being Old in America. Baltimore, MD: Johns Hopkins University Press.

Butler, R. N., Miller, R. A., Perry, D., Carnes, B. A., Williams, T. F., Cassel, C. et al. (2008) 'New Model of Health Promotion and Disease Prevention for the 21st Century', British Medical Journal, 337, pp. 149-150. 
Carlson, M. C., Saczynski, J. S., Rebok, G. W., Seeman, T., Glass, T. A., McGill, S. et al. (2008) 'Exploring the Effects of an "Everyday" Activity Program on Executive Function and Memory in Older Adults: Experience $\operatorname{Corps}^{\circledR}{ }^{\circledR}$, Gerontologist, 48, pp. 793-801.

Cassel, C. (2005) Medicare Matters. Berkeley, CA: University of California Press.

Christensen, K., McGue, M., Petersen, I., Jeune, B. and Vaupel, J.W. (2008) 'Exceptional Longevity does Not Result in Excessive Levels of Disability', Proceedings of the National Academy of Sciences of the USA, 105, pp. 13274-13279.

Cohen, G. (2001) The Creative Age: Awakening Human Potential in the Second Half of Life. New York: Harper.

Cutler, D. M., McClellan, M. and Newhouse, J. P. (1998) 'What has Increased Medical-Care Spending Bought?', American Economic Review, 88 (2), pp. 132-136.

Dannefer, D. (2003) 'Cumulative Advantage/Disadvantage and the Life Course', Journal of Gerontology: Social Sciences, 58B (6), pp. S327-S337.

Estes, C., Phillipson, C. and Biggs, S. (2003) Social Theory, Social Policy and Ageing. Buckingham: Open University Press.

Freedman, M. (1999) Prime Time: How Baby Boomers will Revolutionize Retirement and Transform America. Washington, DC: Public Affairs.

Frick, K. D., Carlson, M. C., Glass, T. A., McGill, S., Rebok, G. W., Simpson, C. et al. (2004) 'Modeled Cost-Effectiveness of the Experience Corps ${ }^{\circledR}$ Baltimore Based on a Pilot Randomized Trial', Journal of Urban Health, 81 (1), pp. 106-117.

Fried, L. P., Carlson, M. C., Freedman, M., Frick, K. D., Glass, T. A., Hill, J. et al. (2004) 'A Social Model for Health Promotion for an Aging Population: Initial Evidence on the Experience Corps ${ }^{\circledR}$ Model', Journal of Urban Health, 81 (1), pp. 64-78.

Fried, L. P. and Hall, W. J. (2008) 'Editorial: Leading on Behalf of an Aging Society', Journal of the American Geriatrics Society, 56, pp. 1791-1795.

Friedland, R.B. and Summer, L. (1999) Demography is Not Destiny. Washington, DC: National Academy on an Aging Society.

Gee, E. M. and Gutman, G. (eds) (2000) The Overselling of Population Aging: Apocalyptic Demography, Intergenerational Challenges and Social Policy. Don Mills, ON: Oxford University Press.

General Accounting Office (GAO) (2001) 'Antiaging Products Pose Potential for Physical and Economic Harm'. Special Committee on Aging, GAO-01-1129.

Glass, T. A., Freedman, M., Carlson, M. C., Hill, J., Frick, K. D., lalongo, N. et al. (2004) 'Experience Corps $\AA$ : Design of an Intergenerational Program to Boost Social Capital and Promote the Health of an Aging Society', Journal of Urban Health, 81 (1), pp. 94-105.

Harper, S. (2006) 'Mature Societies: Planning for our Future Selves', Daedalus, 135 (1), pp. 20-31.

Holliday, R. (2009) 'The Extreme Arrogance of Anti-aging Medicine', Biogerontology, 10, pp. 223-228.

Hollon, S. D. and Dimidjian, S. (2009) 'Cognitive and Behavioural Treatment of Depression', in I. H. Gotlib and C. L. Hammen (eds), Handbook of Depression, second edition. New York: Guilford, pp. 586-603.

Hollon, S. D., Stewart, M. O. and Strunk, D. (2006) 'Enduring Effects for Cognitive Behavior Therapy in the Treatment of Depression and Anxiety', Annual Review of Psychology, 57, pp. 285-315.

Jagger, C., Matthews, R., Matthews, F., Robine, J. M. and Brayne, C. (2007) 'The Burden of Diseases on Disability-Free Life Expectancy in Later Life', Journal of Gerontology: Biological and Medical Sciences, 62, pp. 408-414.

Kalache, A., Barreto, S. M. and Keller, I. (2005) 'Global Ageing: The Demographic Revolution in All Cultures and Societies', in M.
Johnson (ed.), The Cambridge Handbook of Age and Ageing. Cambridge: Cambridge University Press, pp. 30-47.

Kane, R. L. and Kane, R. A. (2005) 'Ageism in Health Care and LongTerm Care', Generations, 29 (3), pp. 49-54.

Keating, N. (2008) Rural Ageing: A Good Place to Grow Old? Bristol: Policy Press.

Kinsella, K. and He, W. (2008) 'An Aging World: 2008'. International Population Reports, P95/09-1.

Klatz, R. (1997) Grow Young with Hgh: The Amazing Medically Proven Plan to: Lose Fat, Build Muscle, Reverse the Effects of Aging, Strengthen the Immune System, Improve Sexual Function. New York: Harper Collins.

Knight, B. G. (2004) Psychotherapy with Older Adults, third edition. Thousand Oaks, CA: Sage.

Knight, B. G., Kaskie, B., Shurgot, G. R. and Dave, J. (2006) 'Improving the Mental Health of Older Adults', in J. E. Birren and K. W. Schaie (eds), The Handbook of the Psychology of Aging, sixth edition. San Diego, CA: Academic Press, pp. 407-424.

Kotlikoff, L. and Burns, S. (2005) The Coming Generational Storm. Cambridge: MIT Press.

Kovner, C. T., Mezey, M. and Harrington, C. (2002) 'Who Cares for Older Adults? Workforce Implications of an Aging Society', Health Affairs, 21 (5), pp. 78-89.

Langa, K. M., Larson, E. B., Karlawish, J. H., Cutler, D. M., Kabeto, M. U., Kim, S. Y. et al. (2008) 'Trends in the Prevalence and Mortality of Cognitive Impairment in the United States: Is there Evidence of a Compression of Cognitive Morbidity?', Alzheimers \& Dementia 4 (2), pp. 134-144.

Laslett, P. (1991) A Fresh Map of Life. Cambridge, MA: Harvard University Press.

Lenze, E. J., Rogers, J. C., Martire, L. M., Mulsant, B. H., Rollman, B. L., Dew, M. A. et al. (2001) 'The Association of Late-Life Depression and Anxiety with Physical Disability: A Review of the Literature and Prospectus for Future Research', American Journal of Geriatric Psychiatry, 9, pp. 113-135.

Longman, P. (1987) Born to Pay. Boston, MA: Houghton Mifflin.

Lutz, W., Samir, K. C., Khan, H. T. A., Scherbov, S. and Leeson, G. W. (2007) Future Ageing in South-East Asia: Demographic Trends, Human Capital and Health Status. Interim Report IR-07-026, IIASA.

Lutz, W., Sanderson, W. and Scherbov, S. (2008) 'The Coming Acceleration of Global Population Ageing', Nature, 451, pp. 716-719.

Martin, L. G., Freedman, V. A., Schoeni, R. F. and Andreski, P. M. (2009) 'Health and Functioning among Baby Boomers Approaching 60 ', Journal of Gerontology: Psychological and Social Sciences, 64b (3), pp. 369-377.

Miller, R. (2009) "'Dividends" from Research on Aging: Can Biogerontologists, at Long Last, Find Something Useful to Do?', Journal of Gerontology: Biological Sciences, 64 (2), pp. 157-160.

Mitka, M. (2002) 'As Americans Age, Geriatricians go Missing', Journal of the American Medical Association, 287, pp. 1792-1793.

Morrow-Howell, N., Hinterlong, J., Sherraden, M. and Rozario, P. (2001) 'Advancing Research on Productivity in Later Life', in N. Morrow-Howell, J. Hinterlong and M. Sherraden (eds), Productive Aging: Concepts and Challenges. Baltimore, MD: Johns Hopkins University Press, pp. 285-311.

National Research Council (2005) Advancing the Nation's Health Needs: NIH Research Training Programs. Washington, DC: The National Academies Press.

Nordhaus, W. D. (1998) 'The Health of Nations: Irving Fisher and the Contribution of Improved Longevity to Living Standards'. Cowles Foundation Discussion Papers 1200, Cowles Foundation, Yale University. 
Nordhaus, W. D. (2003) 'The Health of Nations: The Contribution of Improved Health to Living Standards'. Working Paper 8818, National Bureau of Economic Research.

Olshansky, S. J., Carnes, B. A. and Mandell, M. S. (2009) 'Future Trends in Human Longevity: Implications for Investments, Pensions and the Global Economy', Pensions, 14 (3), pp. 149163.

Olshansky, S. J., Goldman, D. P., Zheng, Y. and Rowe, J. W. (2009) 'Aging in America in the Twenty-First Century: Demographic Forecasts from the MacArthur Foundation Research Network on an Aging Society', The Milbank Quarterly, 87 (4), pp. 842-862.

Olshansky, S. J., Hayflick, L. and Carnes, B. A. (2002a) 'Position Statement on Human Aging', Journal of Gerontology: Biological Sciences, 57A (8), pp. B292-B297.

Olshansky, S. J., Hayflick, L. and Carnes, B. A. (2002b) 'No Truth to the Fountain of Youth', Scientific American, June, pp. 92-95.

Olshansky, S. J., Hayflick, L. and Carnes, B. A. (2002c) 'Position Statement on Human Aging', Scientific American [online], 2 June. Available from: http://www.sciam.com/article.cfm?id=the-truthabout-human-agi [Accessed 19 October 2010].

Olshansky, S. J., Perry, D., Miller, R. A. and Butler, R.N. (2006) 'In Pursuit of the Longevity Dividend', The Scientist, March pp. 28-36.

Organisation for Economic Co-operation and Development (OECD) (2007) 'Directorate for Public Governance and Territorial Development. Ageing and the Public Service: Human Resource Challenges', p. 260. Paris: OECD.

Papp, K. V., Walsh, S. J. and Snyder, P. J. (2009) 'Immediate and Delayed Effects of Cognitive Interventions in Healthy Elderly: A Review of Current Literature and Future Directions', Alzheimer's \& Dementia, 5 (1), pp. 50-60.

Perls, T. T., Silver, M. H. and Lauerman, J. F. (1999) Living to 100: Lessons in Living to Your Maximum Potential at Any Age. New York: Basic Books.

Peterson, P. (2000) Gray Dawn. New York: Three Rivers Press.

Philibert, L. (1968) L'echelle des ages. Paris: Du Seuil.

Rae, M. J. et al. (2010) 'The Demographic and Biomedical Case for Late-Life Interventions in Aging', Science Translational Medicine, 2 (40), p. $40 \mathrm{~cm} 21$.

Rattan, S. I. S. (2005) 'Anti-ageing Strategies: Prevention or Therapy?', EMBO Reports, 6, pp. S25-S29.

Rattan, S. I. S. (2008) 'Hormesis in Aging', Ageing Research Reviews, 7, pp. 63-78.

Rebok, G. W., Carlson, M. C., Glass, T. A., McGill, S., Hill, J., Wasik, B. et al. (2004) 'Short-Term Impact of Experience Corps ${ }^{\circledR}$ Participation on Children and Schools: Results from a Randomized Pilot', Journal of Urban Health, 81 (1), pp. 79-93.

Rowe, J. W., Berkman, L. F., Binstock, R., Boersch-Supan, A., Cacioppo, J., Carstensen, L. et al. (2009) 'Facts and Fictions about an Aging America', Contexts, 8 (4), pp. 16-21.

Rowe, J. W., Berkman, L. F., Binstock, R., Boersch-Supan, A., Cacioppo, J., Carstensen, L. et al. (2010) 'Policies and Politics of Aging for an Aging America', Contexts, 8 (5), pp. 22-27.

Scharlach, A., Damron-Rodriguez, J., Robinson, B. and Feldman, R. (2000) 'Educating Social Workers for an Aging Society: A Vision for the 21st Century', Journal of Social Work Education, 36, pp. 521-538.

Sierra, F., Hadley, E., Suzman, R. and Hodes, R. (2008) 'Prospects for Life Span Extension', Annual Review of Medicine, 60, pp. 457-469.

Speth, J. G. (2005) Red Sky at the Morning. New Haven, CT: Yale University Press.
United Nations (2003) Political Declaration and Madrid International Plan of Action on Ageing. New York: Department of Public Information.

United Nations (2007) World Population Prospects: 2006 Revision Vol. 1: Comprehensive Tables. Department of Economic and Social Affairs, Population Division.

US Senate (2001) 'Swindlers, Hucksters and Snake Oil Salesman: Hype and Hope Marketing Anti-aging Products to Seniors'. United States Senate Special Committee on Aging, One Hundred Seventh Congress, First Session. Washington DC: US Government Printing Office, 10 September.

Van Bronswijk, J. E. M. H., Bouma, H., Fozard, J. L., Dearns, W. D., Davison, G. C. and Tuan, P.-C. (2009) 'Defining Gerontology for R\&D Purposes', Gerontechnology, 8, pp. 3-10.

Walker, A. (1997) Combating Age Barriers in Employment. Luxembourg: Office for the Official Publications of the European Communities.

Wick, G. (2002) ' "Anti-aging" Medicine: Does it Exist? A Critical Discussion of "Anti-aging" Health Products', Experimental Gerontology, 37 (8-9), pp. 1137-1140.

World Health Organization (WHO) (1984) 'The Uses of Epidemiology in the Study of the Elderly'. Technical Report Series 706, Geneva.

World Health Organization (WHO) (2001) 'Health and Ageing: A Discussion Paper'. Geneva: WHO.

World Health Organization (WHO) (2007) Global Age-Friendly Cities: A Guide [online]. Available from: http://www.who.int/ ageing/publications/Global_age_friendly_cities_Guide_English.pdf [Accessed 19 October 2010].

Zarit, S. H. and Zarit, J. M. (1998) Mental Disorders in Older Adults: Fundamentals of Assessment and Treatment. New York: Guilford Press.

\section{Author Information}

S. Jay Olshansky, School of Public Health, University of Illinois at Chicago.

Simon Biggs, School of Social and Political Science, University of Melbourne.

W. Andrew Achenbaum, University of Houston.

Gerald C. Davison, Davis School of Gerontology, University of Southern California.

Linda Fried, School of Public Health, Columbia University, New York.

Gloria Gutman, Gerontology Research Centre, Simon Fraser University, Vancouver.

Alexandre Kalache, New York Academy of Medicine.

Kay-Tee Khaw, Clinical Gerontology Unit, University of Cambridge.

Alvaro Fernandez, SharpBrains, San Francisco.

Suresh I. S. Rattan, Department of Molecular Biology, Aarhus University.

Renato Maia Guimarães, Universidade de Brasília.

Colin Milner, International Council on Active Aging, Vancouver.

Robert N. Butler, International Longevity Center, New York. 